\title{
The Latvians in Sydney
}

\section{Robert Crawford}

People of various ethnic backgrounds who left the regions that comprise modern-day Latvia have long been in Sydney. The two major inflows of ethnic Latvians into Sydney occurred in the aftermath of the 1905 revolution in Tsarist Russia and then in the late 1940s and early 1950s. The organisation and activities of Latvians in Sydney reflect the changing nature of the local community as well as Latvia's changing political situation.

\section{Early contact}

Arriving in 1807, the first Russian ship to anchor in Sydney was captained by Ludwig von Hagemeister, a Baltic German from Latvia. Sydney's first Latvian-born resident was Aaron Woolf, a Jew from Riga who was transported from England in 1829. Some two decades later, seaman Krišsjānis Lūks was the first recorded ethnic Latvian to settle in Sydney, albeit temporarily. ${ }^{1}$ For the remainder of the century, the Latvian presence in Sydney was largely restricted to seamen on leave. Given the importance of Latvian ice-free ports for Russia's international trade, it is unsurprising that Sydney's initial links with Latvia would have a maritime character.

\section{Creating a community}

The effects of the failed 1905 revolution in Russia rippled through to Sydney. Revolutionary activity had been strong in the Latvian provinces. Brutal government reprisals forced activists into exile. Some landed in Sydney via Siberia and Asia, while others arrived from Britain. Latvian émigrés and seamen began to congregate at the home of Jānis Ieviňš at 30A Argyle Place in Millers Point. The Lettish Association of Sydney was established there in 1913. Meeting monthly, its membership was open to all Latvians in Sydney and surrounding areas. It also established a library of Latvian books and periodicals. By 1915 it had 36 fully paid members. ${ }^{2}$

Meetings continued throughout World War I but procuring any information or publications from war-torn Latvia was difficult. As most members were politically oriented to the left, only a few, such as Carl Alksne, enlisted. After the war, Alksne became Sydney's first consular representative for the newly independent Latvian republic. ${ }^{3}$ Political differences became more pronounced in the 1920s. Leftist members supported the Soviet Union and were suspicious of the Latvian state while nationalists held opposing views. Politics and personal differences ultimately undermined the Association's formal activities. In the mid-1920s the library remained the community's sole institution. 
In 1928, the Latvian Club of Sydney was formed, and its founders hoped its apolitical stance would help it flourish. Political differences, however, remained and Latvian Club members were largely nationalists and recent Latvian immigrants. Leftists established the Sydney Latvian Workers' Association in 1930 to encourage self-education, promote the working-class cause, and maintain the old library. ${ }^{4}$ Of the community's divided state, Alksne later recalled: 'When we met in pubs ... we is friends. But when we go to official things, then we start to fight'. Although both organisations' formal activities petered out during the 1930s, events such as Jāni (midsummer) and Latvia's Independence Day on 18 November briefly united Sydney's Latvians. ${ }^{6}$

\section{Sydney Latvian Society}

Latvia lost its independence in 1940 to the Soviet Union and then to Nazi Germany. When the Soviets returned in 1944, thousands fled to the West. Australia's postwar labour shortage offered them a new start. Between 1947 and 1951, some 16,000 Latvians arrived in Australia. The Australian Latvian Welfare Society was established by Sydney's resident Latvians to support displaced Latvians in Europe. However, its focus soon turned to those Latvians settling in Sydney. An information bulletin listing local Latvian events commenced publication in 1950 (and is still published in 2008). The Kultūras Dienas festival proved to be the Welfare Society's most significant legacy. First staged in 1951, it featured concerts, lectures, and theatre performances by local Latvians. ${ }^{7}$ Rotating between state capitals, Kultūras Dienas has since become a key event for all Australian Latvians with a programme that also includes folk dancing, art exhibitions, and sporting competitions.

In 1952 the Welfare Society was dissolved and replaced by the Sydney Latvian Society. Its initial aim was to secure a location where Latvians could maintain their language and culture. ${ }^{8}$ By 1953 there were an estimated 5,000 Latvians in Sydney. ${ }^{9}$ In addition to the various cultural groups, Latvians were also forming professional and sporting organisations. Children attended makeshift Latvian schools across the city on weekends. In November 1953 two terrace buildings at 31 Parnell Street, Strathfield were acquired to create Latvian House. Converting the buildings into their current form took almost a decade.

By the mid-1950s, Latvian House was already the focus of the community's social life. It housed the Latvian primary and secondary schools and Latvian scouts and guides, whilst offering a permanent rehearsal space to the different folk dancing groups, choirs, and the Sydney Latvian Theatre. Community events, such as the celebration of Latvia's Independence Day and the commemoration of the Soviet deportations on 14 June, were held in the main hall, as were the assorted organisations' annual balls or performances. Side rooms accommodated smaller events and private functions. Other groups such as the Latvian Relief Society and the different church congregations also acquired their own properties. ${ }^{10}$ 
Politics remained important, particularly where Latvia was concerned. Alongside Sydney's Estonian and Lithuanian communities, the Latvian community sought to draw public attention to their country's occupation. However, it was the Federal government's 1974 recognition of the Soviet annexation of the Baltic States that cast the community into the public eye. Petitions and letters were sent to Parliament and the press, whilst demonstrators repeatedly heckled Labor Prime Minister Gough Whitlam. Elga Rodze-Ķīsele, an active community member, even stood against the Prime Minister in his seat of Werriwa in the 1975 election. Tellingly, the newly elected Liberal government reversed the recognition.

\section{A new age}

In the late 1980s the community again focused on events in Latvia. Gorbachev's reforms in the Soviet Union enabled Sydney Latvians to reconnect with family in Latvia. Many now travelled to Latvia to revisit their roots and a growing number of artists and dancers from Latvia were permitted to perform for audiences in Sydney and elsewhere in Australia.

Ties with Latvia strengthened when Latvia reclaimed its independence in 1991. Sydney hosted a steady stream of visiting performers, but the Sydney community was also leaving its mark on Latvia. In 1990 and in 1993 the Saules Josta folk dancing group toured Latvia. Australia's first consular representative in Latvia was former Sydneysider Valdis Bērziņš.

Community activity in Sydney is undergoing change. Access to Latvia has meant that Kultüras Dienas is now staged biennially. Old age has changed the nature, and reduced the size and frequency of community events. ${ }^{11}$ Although Sydney's young Latvians are still active community members, their numbers have similarly fallen. Newly arrived Latvian immigrants have not filled this shortfall. Despite these changes, Sydney's Latvian community has consistently maintained its cultural heritage and has made an active contribution to multicultural Sydney.

Robert Crawford is Research Fellow at the Menzies Centre for Australian Studies, Kings College, London

${ }^{1}$ Aldis L Putniņš, 'The Latvians in Australia' in Betty and Antanas Birškys, Aldis L Putniņš, Inno Salasoo, The Baltic Peoples in Australia, AE Press, Melbourne, 1986, pp 64-5

${ }^{2}$ Aldis L Putniņš, Veclatviešu Organizācijas Austrālijā 1913-1948, Austrālijas Jaungaitnieku Apvien̄iba, Footscray Victoria, 1987, p 8

${ }^{3}$ Eriks Jēkabsons \& Valters Ščerbinskis, Latvijas Ârlietu Dienesta Darbinieki, 1918-1991: Biogrāfiksā Vārdnīca, Zinātne, Riga, 2003, pp 48-9

${ }^{4}$ Aldis L Putniņš, Veclatviešu Organizācijas Austrālijā 1913-1948, Austrālijas Jaungaitnieku Apvienība, Footscray Victoria, 1987, p 65 
${ }^{5}$ Aldis L Putniņš, Veclatviešu Organizācijas Austrālijā 1913-1948, Austrālijas Jaungaitnieku Apvienība, Footscray Victoria, 1987, p 101

${ }^{6}$ Kārlis Nīcis, 'Pirms Divdesmit Pieciem Gadiem' in Alberts Priedīits, (ed), Latvieši Austrālijāa, Apgāds Austra, Melbourne, 1953, pp 8-10

${ }^{7}$ Sp Klauverts, 'Sidneja' in Alberts Priedītis, (ed), Latvieši Austrālijā, Apgāds Austra, Melbourne, 1953, p 32

${ }^{8}$ Arvīds Bērziņš, Sidnejas Latviešu Biedrība Trīsdesmit Gados, Sydney Latvian Society Ltd, Sydney, 1982, p 8

${ }^{9}$ Sp Klauverts, 'Sidneja' in Alberts Priedītis, (ed), Latvieši Austrālijā, Apgāds Austra, Melbourne, 1953, p 33

${ }^{10}$ Imants Ronis, 'In Sydney, Life revolves around Latvian House', 6 October 2001, http://latviansonline.com/index/php/kolonijas/article/1963/, accessed 13 August 2007

${ }^{11}$ Imants Ronis, 'In Sydney, Life revolves around Latvian House', 6 October 2001, http://latviansonline.com/index/php/kolonijas/article/1963/, accessed 13 August 2007 